\title{
Strategies for Improving Streetscape Character in the Street Precinct of Ashoka Road, Mysore City
}

\author{
Shobha R, Shankar B
}

\begin{abstract}
Streets in heritage cities are vital elements of public realm system and become a showcase for many celebrations. They not only function as pathways for movement of vehicles, pedestrians, cyclists supporting many societal and occupational activities, but they serve as the places of congregation as well. In India the streets are inherently a place where people meet, congregate, celebrate and also carry business. Each community has its own distinct occasions during which streets becomes the logical setting for people to gather and celebrate. In case of historic streetscapes, they are the carters of histories, with immeasurable evidence about the past events. The city of Mysore has many traditional streetscapes in the historic core exhibiting not only enormous architectural heritage but also has cultural significance. Ashoka Street Precinct, which was historically associated with cultural celebrations like Mysore Dasara during which the spectacular procession took place is situated in the heart of the city. With the shift of these celebrations to an alternative path, the street seems to be losing its' heritage character and glory, though it is associated with many heritages building and precincts, and due recognition. Hence, it needs to be assessed with respect to the character and the physical quality in order to address the street precincts through the course of dereliction and transformation under the scenario of global change which is the inevitable occurrence everywhere. The paper explores the connection and disconnection between the old and the new and examines the process of physical transformation of Ashoka road precinct from being as a cultural street to a commercial street. The study is based on field work, observations, photo documentation and visual assessment. The streetscape analysis, issues and strategies including the measures proposed would aid the authority in formulation and implementation of streetscape guidelines resulting in improving of heritage character of the street precinct.
\end{abstract}

Key words: street precinct, cultural street, dereliction, transformation.

\section{INTRODUCTION}

Street is an unescapable urban space it constitutes the majority of the public realm of an urban area and People experience a city while they move through its streets. The arrangement and visual appearance of built and landscape features are the important elements defining the character of a streetscape. The streets in an historic city play the most important role in enhancing and promoting cultural identity of a place.

Revised Manuscript Received on April 13, 2020.

* Correspondence Author

Shobha R*, Associate Professor in Architecture, School of Planning and Architecture, University of Mysore, Mysore (email: shobharj_2006@yahoo.co.in)

Shankar B, Director of Institute of Development Studies and Professor of Urban and Regional Planning, School of Planning and Architecture, University of Mysore, Mysore (email: doddi43@gmail.com)

(C) The Authors. Published by Blue Eyes Intelligence Engineering and Sciences Publication (BEIESP). This is an open access article under the CC BY-NC-ND license (http://creativecommons.org/licenses/by-nc-nd/4.0/)
The character of a street is a unique and distinguishing quality that differentiates one place from another [1]. Street as the element of the city is the most influencing elements of the urban identity (Jane Jacob). Wesee, feel, and absorb the information presented along the street as we pass through it, and we create a perception about the city. When Kevin Lynch found the five elements of the image of the city, i.e. landmark, path, nodes, district and edge; he admitted that path is the most important element because from there people can recognize the other four elements [2]. A cultural approach to the city produces some important impacts, among them creating safer public spaces, and promoting localism or a sense of identity against homogenizing globalization [3].

\section{BACKGROUND OF MYSORE}

Mysore is popularly known as "the Cultural Capital of Karnataka" and it is the second-largest city in the State of Karnataka. It had a population of 887,446 as per 2011 census figures. It is located at the base of the Chamundi Hills and about $146 \mathrm{~km}$ southwest of the state capital, Bangalore. The city spreads across an area of 128.42 sq.kms. It is located at $12.30^{\circ} \mathrm{N} 76.65^{\circ} \mathrm{E}$ and has an average altitude of 770 meters. The city exhibits both tangible, intangible, natural and built heritage components. The city of Mysuru has a long tradition of celebrating the Dasara festival with grandeur and is integral part of the culture and life in Mysore. The city is known for its palaces, heritage buildings, gardens, boulevards, planned markets and all these are an outcome of significant contributions of Maharajas, Dewans and their talented workmanship. The city is characterized by architectural and urban design elements like vistas, focal points, landmarks, nodes, avenues, plazas etc., make it undeniably the most important cultural heritage city in India. The beauty of the city viewed from Chamundi hills presents a skyline of mansions, clock towers, focal points, statues, palaces of the townscape.

\section{HERITAGE STREET PRECINCTS IN MYSORE}

The heritage street precincts have been identified by the planning authority in Mysore city, the prime ones are the Dasara procession route which includes albert victor and Sayyaji Rao road, Ashoka Road. The city is known for its boulevards of lush green trees lined on both sides of wide clean streets. The Krishnaraja and Narasimha raja boulevards are historic streetscapes identified as heritage roads. The roads around the most visited tourist places Ambavilas and Jaganmohan palaces are the important heritage roads which were listed. The princess road, Vinoba road and Ashoka street are other heritage streets identified by the Planning Authority.

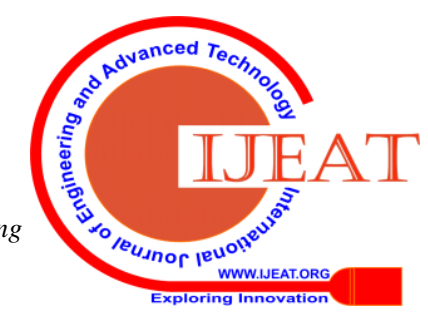


The heritage street precinct Ashoka Road is the old Dasara procession path with a stretch of about $2.7 \mathrm{~km}$ located in the heart of the city.

\section{IV.}

\section{STREET PRECINCT OF ASHOKA ROAD}

Ashoka road is one of the oldest streets existing from the incipient stage; hence, having very high historical significance. It is a narrow street connecting Mysuru Palace and Bannimantap, the path through which the old Dasara procession used to occur up to 1968. In the core area of Mysore city with the palace as the focal point streets radiate from the center. The Ashoka road precinct is one of the main road radiating from center towards the north gate of palace. It is bounded on east and west by residential zones, on west by Mandi Mohalla and on to the east Lashkar Mohalla. Along with the commercial activities on the entire stretch, the street also accommodates different activity zones along the street precinct thus, having diversified crowd gathering. The street connects with many significant heritage buildings starting from Amba Vilas palace, Chamarajendra circle, Town hall, Silver Jubilee Clock Tower, Freemason's Club, Wellington lodge and St. Philomena's cathedral which is considered as the second largest church in Asia. The heritage buildings on Ashoka road precinct are as shown in fig 1. At the entry to the street precinct from Chamarajendra circle is the public zone of town hall and the Dufferin clock tower, are the venue for gathering of public events, performances, protesting, etc. Further along the stretch there are religious zones of many temples, a mosque and famous St. Philomenas church which is also an important tourist zone. Apart from the commercial activity on the street itself, it connects to a commercial zone called Meena bazaar. Shopping at Meena Bazaar has its own significance during the holy Month of Ramzan. Meena Bazaar is frequented by local people for both fabrics and accessories well-known for chain-shopping or link-shopping. Burqas being most shopped for and it is not just clothes and boutique but people also throng the place for enjoying the aroma of samosas and sweets. Now, Ashoka road has been emerged as one of the main commercial streets, for its jewelry showrooms found on either side of the street.

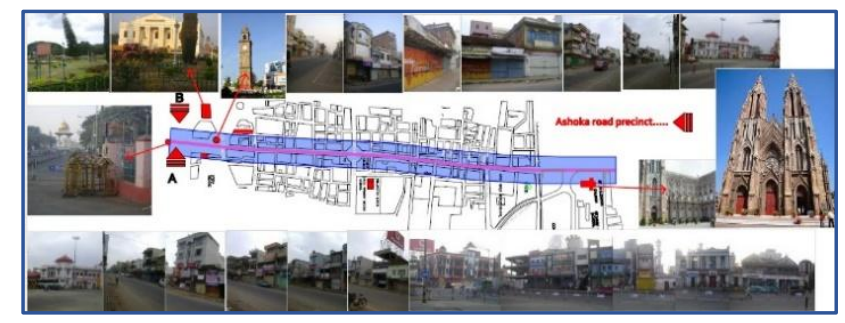

Fig. 1 Ashoka Street Precinct

\section{HISTORICAL DEVELOPMENT OF PRECINCT}

During 14th century, the city consisted of mud fort and the temples at the incipient stage. In the 16th century the fort was reconstructed and the city then consisted of only one street $1.5 \mathrm{~km}$ long towards the north currently Ashoka Road, the road leading to Srirangapatna. Along this road were located most of the residences of princes, nobility and high officers of the State (Lashkar Cantonment). Ashoka road was an extension of existing road called Dodda Pete meaning big commercial street for its business activities during the
Wadiyar's rule which used to cross center of the fort from south to the north. During that period the building use was mixed with the portion of the building facing the road had commercial usage of steel and jewelry shops and behind was the residences. During Dasara procession, the Maharaja on the howdah elephant used to travel on the road from Mysuru Palace to Torch Light Parade Ground in Bannimantap and return on the same route as shown in fig.2. In 1955, the then Maharaja Jayachamaraja Wadiyar, considering that the road is too narrow for the procession, made some changes. The procession used to travel on Ashoka Road (Dodda Pete) and return via Sayyaji Rao Road. Later in 1969, the Ashoka Road was dropped and the procession was held only on Sayyaji Rao Road [4].

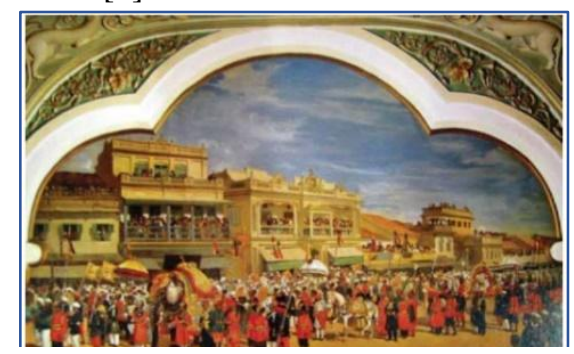

Fig.2. Dasara procession along Ashoka road (1920s and 1930s)

\section{LAND USE ALONG THE STREET PRECINCT}

The land use along the Ashoka road, the street precinct is dominated by commercial activities and it constitutes $60 \%$ of the land use, followed by $28 \%$ mixed use of residential + commercial and the remaining $12 \%$ is public and religious. The street precinct is accommodating diverse uses like commercial, residential, public and semipublic uses.

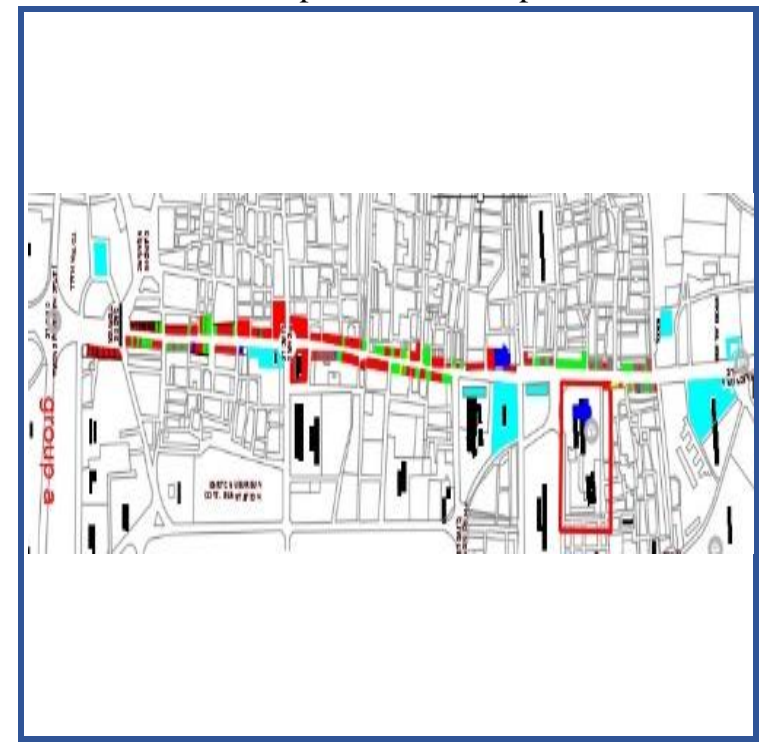

Fig.3 Land Uses along the Ashoka Street Precinct

Published By:

Blue Eyes Intelligence Engineering \& Sciences Publication

(C) Copyright: All rights reserved. 

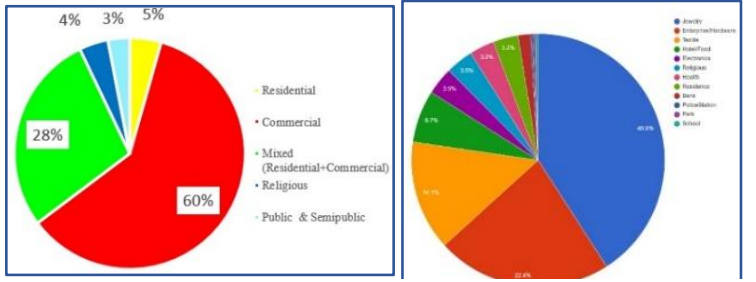

Fig.4 Building Uses along the Ashoka Street Precinct The majority of commercial activities here are jewelry, hardware and textile shops constituting 40.9\%, 22.4\% and $14.1 \%$ respectively as shown in fig. 4 .

\section{VII.}

\section{STREETSCAPE CHARACTERISTICS}

Mysore city core has hierarchy of street network of arterial, sub-arterial and local roads. Ashoka road is an arterial road originating from the Palace and run radially outside leading to Srirangapatna. This is one of the important main roads in the core and intersected by several sub arterial and internal streets of varying widths organically. The intersection points are the nodes which are the points of focus. The existing streetscape character displays the street precinct as an enclosed road with clear building alignment on both sides. It forms a vista connecting Palace and Chamrajendra circle, passing through silver jubilee clock tower, nodes like Nehru circle, St. Philomena's church circle and joins fountain circle. The streetscape is narrow, not uniform in width and it varies between $12 \mathrm{~m}-15 \mathrm{~m}$ wide along the stretch. There are compactly placed built without side setbacks giving continuity on either side of the street and also the buildings start directly from the street edge giving a strong edge characteristic to the streetscape. The streetscape accommodates interesting nodes at intersections along the $2700 \mathrm{~m}$ stretch of Ashoka road with unique characteristics. The solid void analysis displays the voids constituting streets, parks, open spaces around town hall, church, nodes and a neighborhood park near to church premises. Solids represent mainly compact built form of buildings with commercial, mixed use of commercial and residential along the road. It also represents buildings like town hall and St. Philomena's church where open space prevails over built.

\section{A. The views}

The view from the street precinct is focused on the features of interest like landmarks, nodes giving the street a sense of identity. One travels on the streetscape, that exhibits good directional view towards the Chamarajendra circle, palace and enjoys a cone view towards big clock tower and town hall. The alignment of the street is varying making only part of the street stretch visible from a single point, not all structures are visible at one glance thus closing and opening the views creating visual interest.

\section{B. Height of buildings, site coverage and setbacks}

In the street precinct buildings are of varying heights and the structures are of $G, G+1, G+2$ or $G+3$. The buildings on Ashoka road are aligned to the road without front setbacks. The site coverage of all the buildings is $100 \%$ except Town hall and St. Philomena's cathedral, and where the unbuilt space dominates over the built spaces, all other buildings have no setbacks left on all sides.

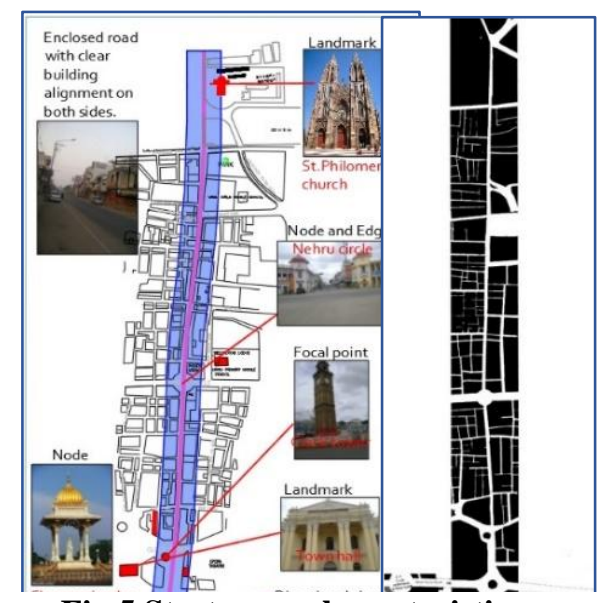

Fig.5 Stretscape characteristics

\section{Architecturee}

The significant land marks located in Ashoka street precinct are known for their monumental character and distinctive architectural style like town hall an edifice in Greeco Roman style and St Philomena cathedral in neo gothic style that are listed under grade- 1 heritage buildings. Dufferin clock tower is an important focal point signifying an historical event. The intersection of Ashoka Road and Albert Victor Road is a well-known node and landmark in the city known as Chamarajendra circle wherein stands the marble statue of Jaya Chamarajendra Wodeyar under golden plated onion dome and boldly executed brackets supported by columns. Nehru circle located at intersection of Irwin Road and Ashoka Road having the similar characteristics of Krishna Rajendra circle wherein the surrounding public buildings are circular in shape responding to the configuration of node geometry exhibiting a noticeable edge characteristic. The fountain circle node is an entry point to Mysuru from Bengaluru Road, wherein an exquisitely carved sculptures of fish adorning at five corners in the bottom with birds in the middle portion of the fountain. The top of the fountain is adorned with water spouting toy. The fountain circles in the city were planned and located in such a way that they welcomed visitors at the City's entry points. All these elements contribute to the identity of the streetscape.

\section{Built Form Characteristics}

Typologies and Character: The precinct is dominated with the commercial buildings and the character of the existing buildings displays majorly two typologies. They are the buildings with traditional character and contemporary buildings. The modern typology of buildings found in the street precinct could be grouped into (a) old structures demolished and new buildings which have come up are modern in character or (b) only the facades of the old buildings modified into modern character. When the design of traditional buildings is analyzed they are of the typologies as single floor buildings with only residential use, double floor buildings with commercial usage at the ground floor and residential at first floor level or double floor with front portion completely commercial and the residential behind depicted in fig. 6 .
Published By:

ces Publication

(C) Copyright: All rights reserved.

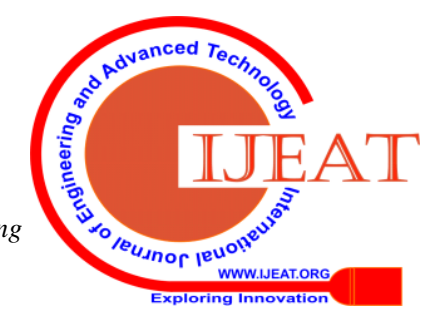


The identified architectural elements of these remaining traditional buildings contributing to streetscape character are sloped roof with clay tiles, sloped roof with monkey top dormer, decorated parapets, decorated eaves projection, open balcony with pillars, colonnaded verandah etc.as shown in fig 7 .

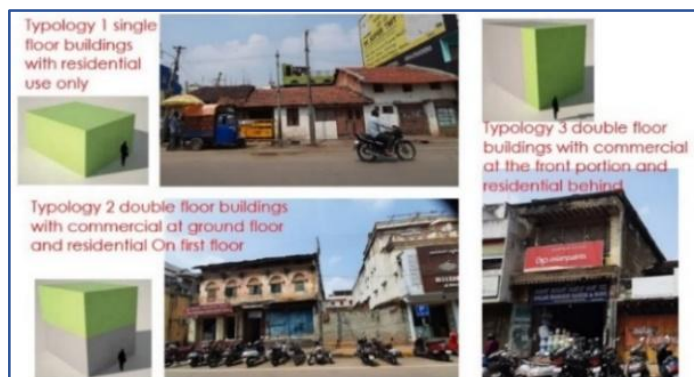

Fig. 6 Typology of Traditional Buildings

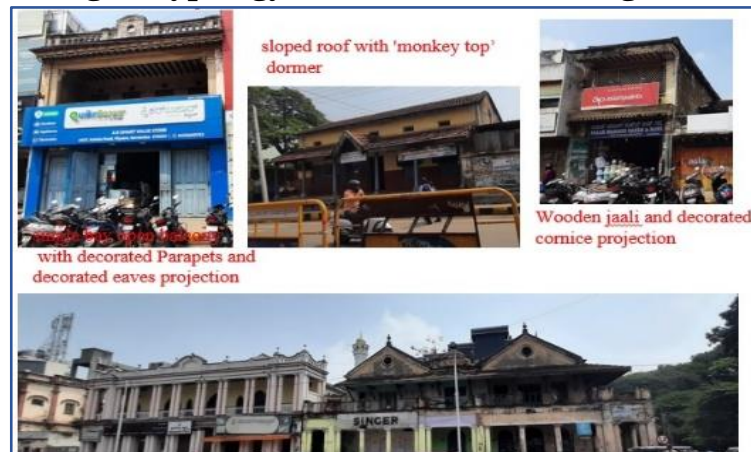

Fig. 7 Architectural Elements in Traditional Buildings

\section{ISSUES}

The delink as a cultural street has forsaken the precinct character it exhibited historically leading to rapid transformation as a commercial street without any respect for its historical context. The Urban grain of the Ashoka road precinct has changed significantly in last few decades. From the image of an old Dasara procession route, it has become a commercial route. The current issues of the street precinct identified are

\section{Built Form Characteristics}

\section{A. Transformation of Building Use}

Initially the buildings were majorly residential with minimum commercial use. In recent decades, the buildings have undergone wide-range of transformation and it has become reverse either by changing completely into commercial or with maximum commercial use and minimum residential usage. As shown in table 1. in the existing scenario residential building use is $4 \%$ which is the less and purely commercial is $60 \%$ being the highest. These transformations are directly reflected on the changes in built character of traditional buildings.

Table.1 Building Use Transformation

\begin{tabular}{|c|l|c|c|}
\hline sl.no & Building use & No's & \% \\
\hline 1 & Residential & 13 & $4 \%$ \\
\hline 2 & Commercial & 182 & $60 \%$ \\
\hline 3 & $\begin{array}{l}\text { Mixed } \\
\text { (Residential+Commercial) }\end{array}$ & 89 & $29 \%$ \\
\hline 4 & Religious & 12 & $4 \%$ \\
\hline 5 & Public \& Semi public & 9 & $3 \%$ \\
\hline \multicolumn{2}{|c|}{ Total } & $\mathbf{3 0 5}$ & \\
\hline
\end{tabular}

\section{B. Transformation of Built form}

The noticeable issues with the Elements of physical form of a building are

1. Size and Shape: The area around the street precinct historically developed during the early phase of city development and the plots have developed organically with irregular sizes in a compact form. In the recent decades due to increased demand for commercial space, the existing buildings on many of the bigger plots have been demolished, subdivided and sold to many owners. This has resulted in oblong size of the plots and the built mass of narrow rectangular shape. Partitioning of buildings by owners and renting them for different commercial purposes has largely altered the physical character of the traditional buildings. With the number of shops in each building increasing, the level of change of physical character of the building is also increasing.

2. Height and skyline: Historically the residential and commercial structures were ground or ground plus one floor

\section{Table.2 Building heights}

\begin{tabular}{|c|c|}
\hline No. of floors & No. of buildings \\
\hline Ground & 49 \\
\hline G+1 & 113 \\
\hline G+2 & 94 \\
\hline G+3 & 24 \\
\hline G +4 & 4 \\
\hline Total & $\mathbf{2 8 4}$ \\
\hline
\end{tabular}

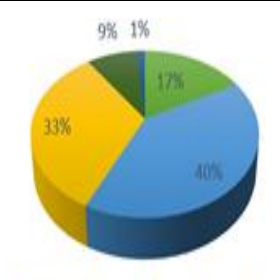

wGround $\|G+1=G+2=G+3\| G+1$

having harmonious skyline. From past few decades under the pressure of urbanization many buildings that have come up are ground plus two and ground plus three floors which constitutes about $43 \%$ together (given in table 2). This has resulted in more variation of the skyline causing loss in integrity and character as well as visual disturbance as shown in fig. 8. The skyline of the streetscape is an identity hence a distinctive asset that needs to be protected.

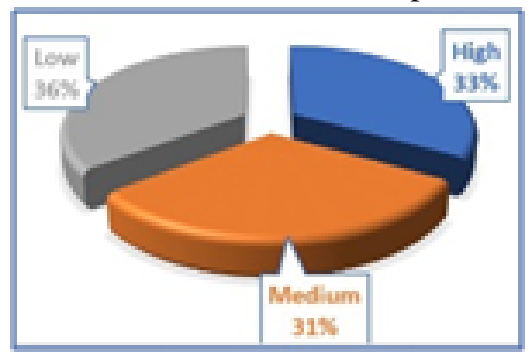

Published By:

Blue Eyes Intelligence Engineering \& Sciences Publication 


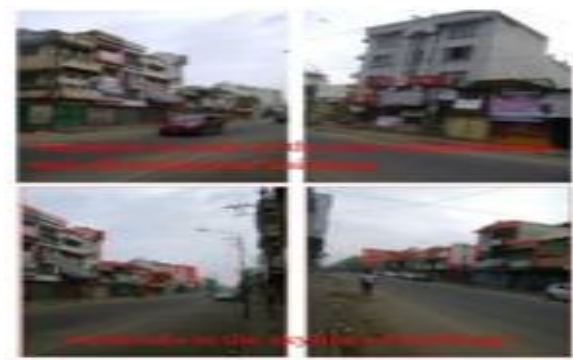

Fig.8.Height and skyline variations

3. Design, Material and Façade: The majority of the buildings in the street precinct are undergoing changes in the built form characteristics. Based on the level of changes, the buildings are grouped into three categories as buildings with low, medium and high levels of changes. Building with low level of change is about $36 \%$, they are with minimum alterations without damaging the original character of buildings. Buildings with medium level of changes are where retaining the old structure with modifications to the façade using modern materials like aluminum boards and glass (in fig.9)

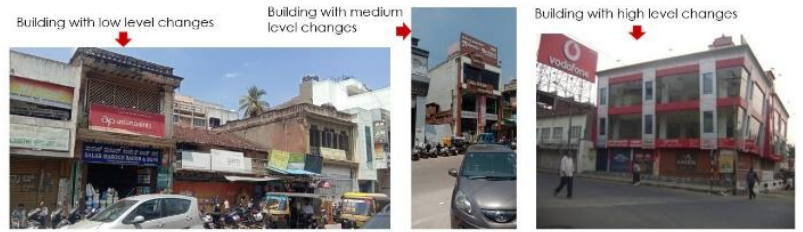

Fig. 9. Level of changes in built character

giving modern character to the façade. Buildings with high level of changes is the category includes demolished old buildings and constructing new contemporary buildings with new design and materials. The field survey data shows that the buildings under the category of medium and high level of changes together constitute $64 \%$ and has become the dominating character of the street precinct today overshadowing the traditional built forms. There are noticeable changes with architectural styles and materials all along the stretch of the street.

4. Building line: Building line helps to maintain and enhance street character. At many places in the street precinct, the consistent building line is not maintained. The entrance steps to shops are illegally encroached onto the sidewalk or the building is much setback from the street edge thus disturbing the visual continuity of the street.

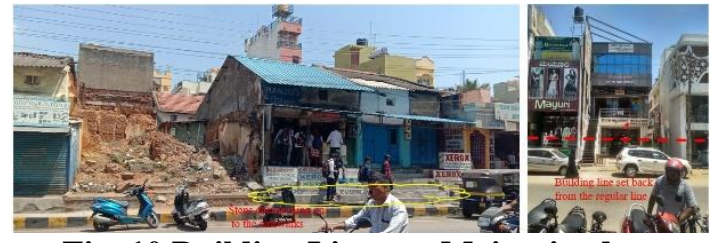

5. Building Byelaws: There are no specific building byelaws formulated for heritage street precincts except a few general regulations regarding façade character and signages. Ashoka road comes under the zone of special control of Amba Vilas palace fort. There are general height restrictions in this zone according to which maximum height allowed is $14 \mathrm{~m}$ within a radius of $200 \mathrm{~m}$ to $400 \mathrm{~m}$ from the monument premises. Taking advantage of this,
Fig. 10 Building Line not Maintained

the owners are either renovating the old traditional buildings that were initially designed as ground or ground +1 structures by adding up floors or old buildings are pulled down raising up $\mathrm{G}+2$ and $\mathrm{G}+3$ structures without respecting the surrounding context which has led to too much variations of scale of buildings, skyline and character.

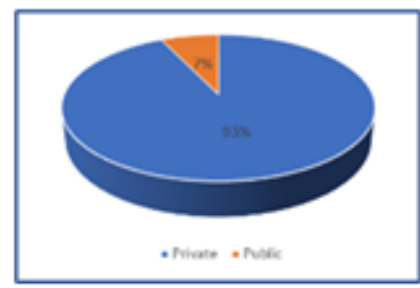

6. Ownership: The majority of ownership of land in the street precinct is with private. The dominating typology is the private ownership of residential, commercial and mixed use of commercial and residential buildings. It constitutes about $93 \%$ and the remaining being public ownership to include religious and institutional buildings. High percentage of land ownership is under private and in the absence of development control regulations, the owner has full liberty to modify according to his requirements and many buildings have undergone high level of transformations ensuing changes in built character. The demand for more commercial space has instigated the owner for the division of the building into number of shops. Historically majorly each building had one shop along with the residence. Currently more than $53.33 \%$ of the buildings accommodate more than one shop (shown in table 3) increasing the occupancy rate of each building causing many issues like increase in population density of each building, attracting more visitors leading to growing pressure on traffic flow and parking problems.

Table.3 Buildings with no. of shops

\begin{tabular}{|l|c|c|}
\hline $\begin{array}{l}\text { No. of shops in } \\
\text { each building }\end{array}$ & No's & $\%$ \\
\hline 1 shop & 127 & 47.04 \\
\hline 2 shops & 68 & 25.19 \\
\hline 3 shops & 43 & 15.93 \\
\hline 4 shops & 16 & 5.93 \\
\hline 5 shops & 11 & 4.07 \\
\hline 6 shops & 6 & 2.22 \\
\hline Total & 271 & \\
\hline
\end{tabular}

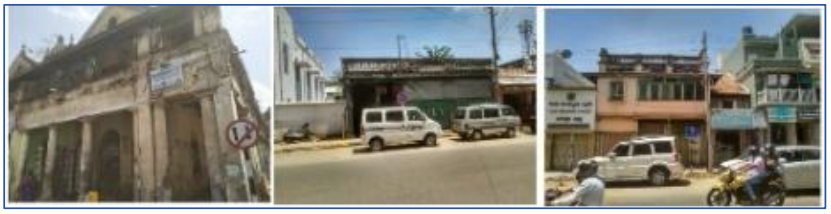

Fig.11 Abandoned and neglected traditional buildings
Published By:

Blue Eyes Intelligence Engineering \& Sciences Publication

(C) Copyright: All rights reserved.

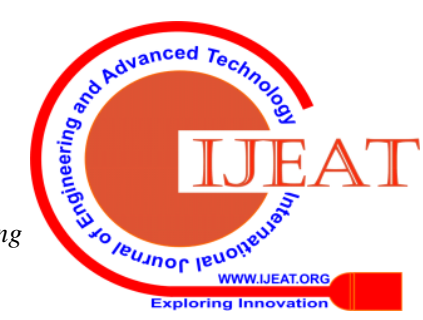


Besides this many building with traditional character is either neglected without proper maintenance by owners or some of them have been completely abandoned(fig.11) due to various reasons consequently devaluing the context of the streetscape.

\section{Physical Quality of the Street}

The physical attributes like paving, seating, shading, lighting, signages, landscaping, accessibility, traffic, maintenance and cleaning, which are influential on design and quality of urban space in a streetscape. As shown in fig. 11. the issues with the quality of these attributes in Ashoka road are as follows

\section{A. Road width and Traffic Flow}

The number of users is high as it is a street with commercial activities and also a major tourist route. Compared to the number of users the street width and capacity is less resulting in conflicts between parking, pedestrians and vehicle movement. The vehicular parking is allowed on the street but proper line demarcation of parking bays and the type of 4 wheelers parking is not clearly done. As a result, the vehicles are parked haphazardly on the street creating an unpleasant scene.

\section{B. Road/Pedestrian Walkway Condition and Accessibility}

Poor maintenance of streetscape and side walkways is discernable at many places in the street precinct resulting in interruption to the easy movement of vehicles and pedestrians. Even the width of the walkways is less compared to the number of users. In many places, the walkways are encroached by street vendors disturbing pedestrian movement. Hence, the accessibility in the street precinct is low.

\section{Street Furniture Quality}

Seating/benches are commonly used furniture but not provided in the street precinct as the road width is less and lacks enough space to accommodate. Trash bins are provided randomly and not enough in number. This has resulted in littering at many places giving an unpleasant view.

\section{Street Lighting and Safety}

Lighting is provided adjacent to the side walkways on either side of the street. It is just serving the purpose of safety at night rather than as a design element thus contributing least to the aesthetic value of the street. The street lighting poles cluttered with electric lines adding to disfiguring of the streetscape character.

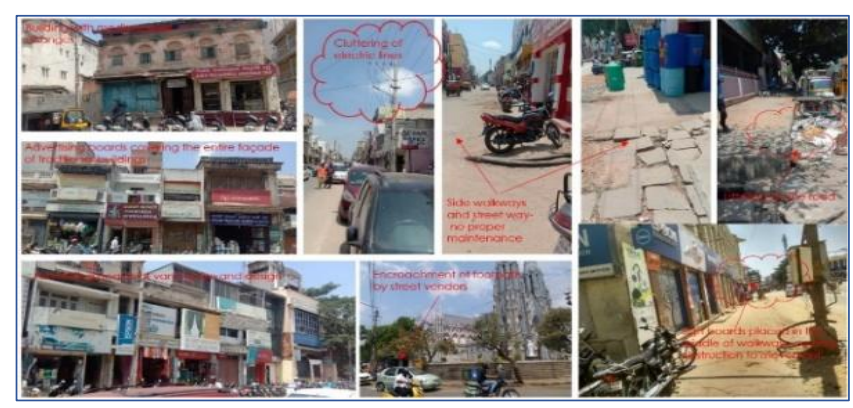

Fig.12 Issues of physical quality of streets

\section{E. Signage}

The buildings are covered with hoardings and signages and are not uniform in designs. Putting up hoardings / Advertisement Boards or posters / sign boards in the street precinct has resulted in obstruction of views and defacing the beauty of the streetscape.

\section{F. Landscape}

There are many boulevards with trees aligned on both sides of the streetscape contributing to the aesthetic quality in core area of Mysore. Whereas in Ashoka road precinct, the tree locations are not planned, they exist randomly. Except few trees any other kinds of landscaping features are not found. The landscape attribute is very minimum not contributing anything to the character of the street.

\section{G. Maintenance and Cleanliness}

Longstanding litter, undesirable public work debris is a common scene at many places across the street precinct. The maintenance is the most influential factor in the quality of urban streetscape. The street is not maintained properly and presents an unpleasant view for visitors and tourists moving along the streetscape.

\section{STRATEGIES}

- Preparation of specific Conservation guidelines for urban heritage street precincts.

- The guidelines regarding character of buildings, height of buildings and building line have to be formulated.

- The guidelines and regulations for owners regarding subdivision of plots and division of existing built space into number shops have to be framed and imposed.

- The existing buildings with modern facades need be pulled down and should adopt the style of architecture prevalent in the street precinct in harmony with the neighboring buildings.

- The Financial assistance to owners is an effective tool which could be adopted to encourage conservation of traditional buildings. Incentives for owners who have abandoned and neglected the traditional buildings can motivate them in retaining and maintaining their traditional buildings. Grants and loans could be provided for owners to modify their façade to the original character.

- In case of renovation of existing traditional buildings, the concept of facadism i.e. retaining the facade of a historic building having architectural value with modifications to the behind structure, could be adopted in order to retain the original character of the street precinct.

- Parking places are inevitable in today's urban context but when historic streetscapes are considered they were not designed then for today's parking requirement which is huge. This is resulting in lot of traffic issues in core areas.

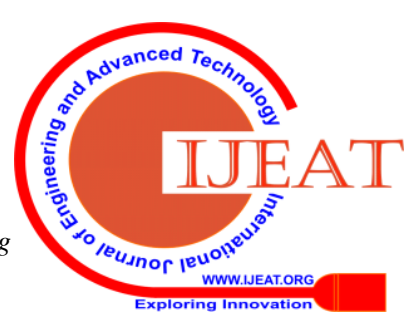


Since the whole stretch of Ashoka road is narrow pedestrianizing and relying upon traditional transport system of tanga and electric motor vehicles of different capacities beautifully designed suitable to Mysore's context might be a remarkable idea.

- $\quad$ The typologies of the shops when looked at, the jewelry shops are maximum and they have their roots in the street precinct. But the hardware shops have to be discouraged on the street as they cause lot of traffic issues while loading and unloading, instead what Mysore is known for i.e. arts and crafts related shops like rosewood, sandal wood Carving, Mysore painting, pottery and stone sculpturing which have their routes in the surrounding residential zones and are still practiced have to be encouraged. Government should provide assistance to artisans to set up their shops and workshop which would attract lot of tourists thus reviving both tangible and intangible heritage and this transforms the street as a cultural tourist heritage street precinct.

- Interesting activities in relation with the culture of the city could be organized in the street precinct for the tourists and localists making the street more attractive and diversified. The street should be developed as an important Cultural Route to revive the glory back. In case of tourists shopping is part of their travel experience hence a link should be established between tourist activity and shopping. For example, the local arts and crafts, there are artisans whose wood carving and stone sculptures shops located at the famous Mandi Mohalla on the Ashoka Road in Mysore. The street can become the platform for exhibiting these creative art works during peak season of tourists visits along with the potentials of Meena bazaar as a shopping zone should be realized. On Sundays the street precinct is active with its commercial activities' maximum till 6 p.m., therefore other activities like evening ride on a tanga which is already a famous activity around palace could also be implemented on this road.

- Urban heritage Street Design Guidelines have to be formulated to address the issues of physical quality of the street precinct. In several cases, along with the appearance of the built the physical quality of the streetscapes also is imperative that makes places unforgettable. The design of an individual building, however good, cannot transform a bad quality of layout into an exciting one. A layout with well-planned and well-designed physical attributes, can mask any inadequacies in the design of individual buildings. In order to create a sense of place the physical attributes should be designed logically in an orderly and coherent way to revitalize the visual quality of the street precinct. Hence for each physical attribute specific design guidelines have to be formulated with the contextual considerations. The design, location, size, material, color of physical attributes like street lighting, signages /hoardings, landscape, trash bins and sidewalk ways etc. have to be designed so that they are in harmony with the context and enhance the character of the streetscape.
Ashoka road is transforming its historic buildings to accommodate commercial activities, adopting contemporary architecture in existing traditional streetscape. In the name of development older, smaller heritage buildings, which are unique to the area, are losing its character. Today, it faces high challenges to combine commercial activities with the preservation of historic buildings and to re-establish the cultural significance once it possessed. To regenerate the original character and cultural significance, the combination of appropriate conservation regulations, measures to improve and maintain physical quality and strategies to link the streetscape, activities and culture would transform the street into a cultural tourist heritage street precinct.

\section{REFERENCES}

1. Norberg-Shulz, C. (1963). Intentions in architecture. Oslo:Universitetsforlaget.

2. Lynch, K. (1960). The Image of the City. Cambridge MA, The M.I.T Press

3. Rana, Ranta \& Piracha, Awais, (2007), Cultural frameworks, in Urban Crisis Culture and the Sustainability of Cities, ed. M. Nadarajah and Ann Tomoko Yamamoto (Tokyo: United Nations University Press.

4. Urs Nanjaraja, (2019), 'Once a royal route, Ashoka road is now a symbol of neglect' The Times of India, dec-12

5. Mehdi Fallahi Panah and Shankar B (2017) "Effects of Physical Quality of Central Streets of Sabzevar City, Iran, International Journal of Scientific \& Engineering Research, Vol.8, Issue 6, pp- 525-533

6. Mehdi Fallahi Panah., Shankar B, (2017) Visual Presentation of Sensitivity of Streetscape in the Heart of Sabzevar City, Iran, International Journal of Scientific \& Engineering Research, Vol. 8, Issue, Issue 6, pp 1066-1072

7. Kiruthiga.K, Thirumaran.K,( 2019) "Efeects of urbanization on historical heritage buildings in Kumbakonam, Tamilnadu, India", Frontiers of Architecture research, 8, 94-105.

8. Tandon Meetha, Sehgal Vandana, (2017) "Traditional Indian streets: A spatial study of the streets of Mathura" Frontiers of Architecture research, 6, 469-479.

9. Mahmoudi Mohadeseh, (2012) "Physical attributes of streetscape in the inner city of Kuala lumpur: Case study of Bukit Bintang street and Tun Perak street" Dissertation Submitted to the University of Malaya, Kuala Lumpur.

\section{AUTHOR PROFILE}

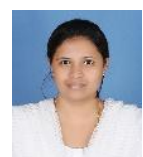

Shobha $\mathbf{R}$ received a Bachelor's degree in Architecture and $\mathbf{M}$ Tech in Urban and Regional Planning degree in 2012 from the University of Mysore, Mysore. She is working as Associate Professor in Architecture, School of Planning and Architecture, University of Mysore, Mysore. She is pursuing her Doctoral degree at the University of Mysore, Mysore in the field of Urban and Regional Planning. Her research interest includes heritage precinct, planning, and conservation.

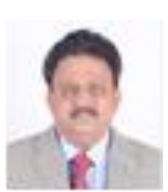

Prof. B. Shankar received a B.E. degree in Civil Engineering in 1984, an M.U.R.P degree in Urban and Regional Planning in 1989 and a Ph.D. degree in Urban and Regional Planning in 1997 from the University of Mysore, Mysore. He is presently working as Director of the Institute of Development Studies and Professor of Urban and Regional Planning, School of Planning and Architecture, University of Mysore, Mysore. His research interests to include Urban Planning, Urban Poverty, Community Development, and Heritage Conservation, Urban Design and Planning. 